\title{
SPACE SYNTAX ANALYSES IN DEFINING THE CONNECTION OF DEVELOPMENT CENTERS IN BALIKPAPAN
}

\author{
Sherlia ${ }^{*}$, Nadia Almira Jordan ${ }^{1}$, Elin Dyah Syafitri ${ }^{2}$ \\ ${ }^{1}$ Architecture, Institut Teknologi Kalimantan, Jalan Soekarno-Hatta KM.15, Karang Joang, Balikpapan, \\ ${ }^{2}$ Urban Regional and Planning, Institut Teknologi Kalimantan, Jalan Soekarno-Hatta KM.15, Karang Joang, Balikpapan, \\ Kalimantan Timur \\ *Corresponding author; Email: sherlia@lecturer.itk.ac.id
}

\begin{abstract}
Old town means an historic or original core of a city which signifies the city's origin growth. When the city develops and expands its built area, the emergence of a new development center will be inevitable. This study focuses on the connection of the old and new development center of Balikpapan city. In defining the mentioned connection, the authors use Space Syntax theory and depthmapX[net] software to analyze connectivity, integration and choice of the observed networks. Space Syntax analyses helped defining the spatial configuration of the old and the new center of development of Balikpapan city which has higher scores in main connectors and lower scores in local streets which also defines the movement and accessibility of the observed area. It is hoped that this study would be beneficial in guiding the planning and design of the future development of Balikpapan city that is appropriate with its spatial configuration.
\end{abstract}

Keywords: Spatial configuration; space syntax analyses; development centers.

\section{INTRODUCTION}

Old town means an historic or original core of a city which signifies the origin growth of that city. When the city develops and expands its built area, the emergence of a new center of development will be inevitable. Morphologically, the old center and the new center of development will have different urban textures that characterized its own morphology characteristics. The aspect of movement is also a focus of morphological investigation. Morphological view of street patterns is taken by Bill Hillier as abstract configurations in order to understand their inherent properties and their effects on movement (Kropf, 2011). This study focuses on the connection of the old center and the new center of development of Balikpapan city. In defining the mentioned connection, the authors use Space Syntax theory and depthmapX[net] software to analyze the connectivity, integration and choice of the observed networks.

Balikpapan is chosen as the case study because the authors aspire to gain a comprehensive understanding of the city's spatial configuration and characteristics through the study of the connection of the old and the center of development in Balikpapan city. Growing as an oil city, oil industry was the key that triggered the development of Balikpapan from a coastal fishermen settlement area into a city. The city develops and expands into its current phase, where the city has several centers within the city (Tarigan, Samsura, Sagala, \& Wimbardana, 2017). It is hoped that this study would be beneficial in guiding the planning and design of the future development of Balikpapan city that is appropriate with its spatial configuration.

\section{PREVIOUS STUDIES}

\section{Configuration Approach in Urban Morphology}

This study looks at Balikpapan city through morphological lens as been studied by Kropf in 2009 and 2011, particularly the type or configuration theory of urban morphology. Linking the study of city's spatial configuration and urban morphology highlights one of the morphological investigations of the aspect of movement (Kropf, 2011). This brings Space Syntax as the configurational approach to urban morphology. The configurational approach in urban morphology can be represented by Space Syntax as it seeks to understand the spatial structure of settlements through a range of analytical methods. In addition, at the scale of settlements, the theoretical basis of the approach is the relationship between spatial structure and the generic function of movement (Kropf, 2009).

The fundamental aspects of the space syntax approach are the focus on space and the relationships between space and movement. In 1984, Hillier and Hanson defended a theory regarding an establishment of descriptive autonomy for space that enabled the consideration of a wider morphological variety to reflect the relationships of space and society. Then in 
1987, Hillier et al. defined the meaning of spatial configuration as it is a key concept in this approach which means the relationships between two spaces within a system considering their relationships with all the other spaces in that system. Furthermore, the configuration of the urban layout is the main generator of movement patterns as space syntax suggested, which means movement and space use in general cannot be separated from its urban form (Oliveira, 2016).

\section{Space Syntax Theory}

Space Syntax theory describes quantitatively the definition of connectivity because it expresses the spaces mathematically. Originally pioneered by Bill Hillier, Julienne Hanson and their colleagues, Space Syntax theory is continually developed until today. In Space Syntax, the spaces are defined as isovist, axial space and convex space. Isovist (also called view shed or visibility polygon) is the field of view from any particular point. Axial space means a straight-line and possible path and convex space is an area in which all points within the polygon are visible to all other points. Then space being observed is analyzed according to any or all of these conceptions of space with the help of a set of measures that was developed to help describe and quantify the morphology of the urban structure, the open spaces and street pattern (Hillier, Burdett, Peponis, \& Penn, 1986).

The measures comprised of local and global measures. The following measures are the most relevant to the current study which are connectivity as in local measure; integrity and intelligibility as in global measures. Connectivity in Space Syntax refers to the number of the axial lines or spaces that are directly connected to any line or space. A connection between two axial lines is said to be shallow or deep when a few or many intervening lines have to be traversed when going from one to the other. It is considered a local measure, since this information is directly observable from a space.

Integrity is a fundamental property of the spatial organization of towns and urban areas. The integration value of a space expresses the relative depth of that space from all others in the graph (Hillier, Burdett, Peponis, \& Penn, 1986). It measures how deep the system is from particular point with how deep or shallow theoretically it can be. High values indicate spaces from which the space is shallow, that is a space which could be reached with fewer turns. Low values indicate spaces which tend to be segregated.
System's intelligibility is defined as the "correlation between global integration and connectivity". It indexes the degree to which numbers of immediate connections a line has - which can be seen from that line - are a reliable guide to the importance of that line in the system as a whole i.e. the whole can be read from the parts. Intelligibility values can be used to quickly compare between different environments. Intuitively it means that in a layout of high intelligibility, information about local connectivity allows a person moving through the system to comprehend the overall structure of the configuration. The stronger a correlation, the more global configuration of a space may be inferred from its directly observable local connections. Hillier asserted that integration and intelligibility are key properties of urban layouts, and that the pattern of pedestrian (and vehicular) movement in urban area is determined in the first instance by the pattern of integration, and only secondly by the local properties of the space (Hillier, Burdett, Peponis, \& Penn, 1986).

\section{METHODOLOGY}

\section{Analyzing the Connection of Old Center and New Center of Development of the City}

First, the authors identified the origin growth and the expansion development of Balikpapan city using overlay technique on figure ground maps of the city that was divided into several phases of development: year 1987, 1996, 2016, and 2019. The years represented the significant development that occurred in the city. In addition, desktop research on historical literatures of the city was also done to obtain information and location regarding the important buildings and neighborhood of the old center and the new center of development of the city.

Second, after the old center and the new center of development of Balikpapan city were identified, the study moved to define the connection between the two centers by defining the main connectors then analyzing the connection using Space Syntax analyses: connectivity, integration and choice.

\section{Analyzing the Connection Using Space Syntax Analyses}

The connectors which are in the forms of main and local streets within the observed areas then analyzed using Space Syntax theory by drawing axial lines map in depthmapX[net] software. Then, connectivity, integration, and choice analyses were applied to the axial lines map. Connectivity measures how many streets connect to that street. A high score of 


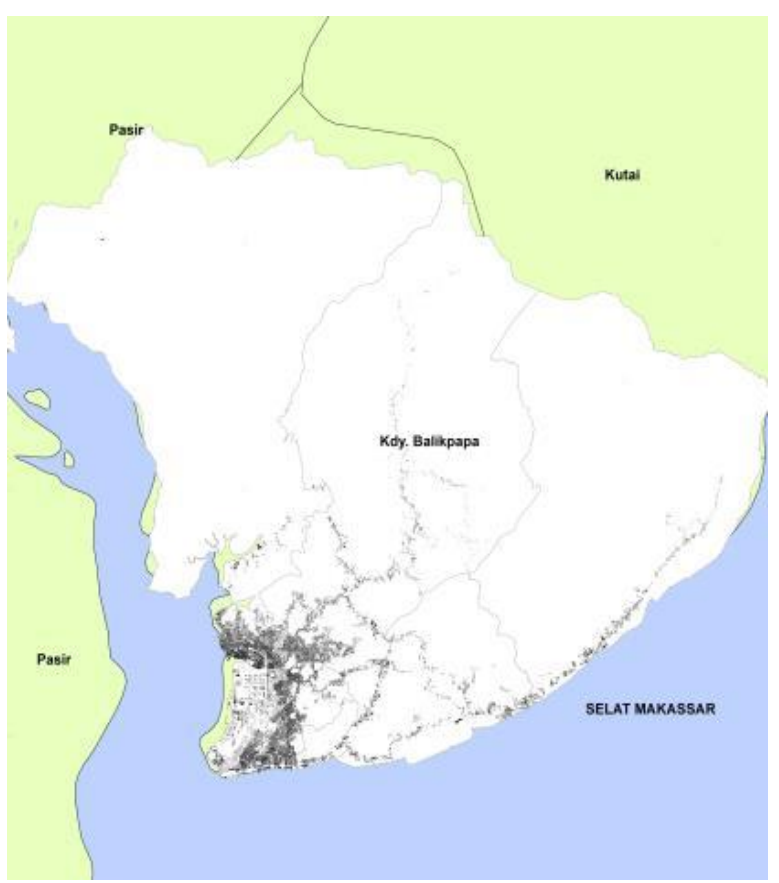

(a)

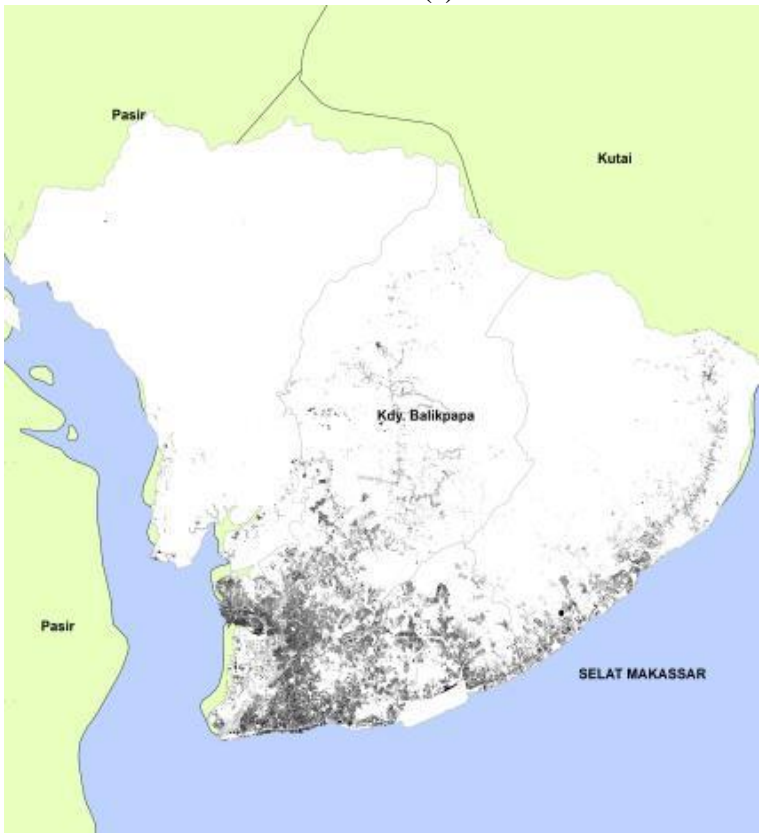

(c)

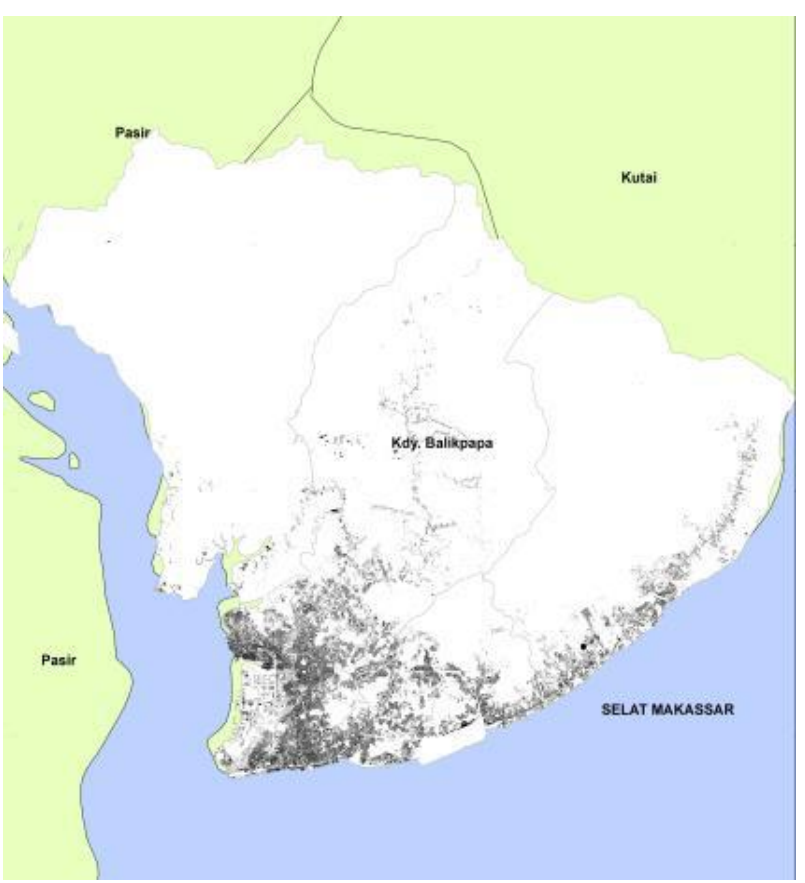

(b)

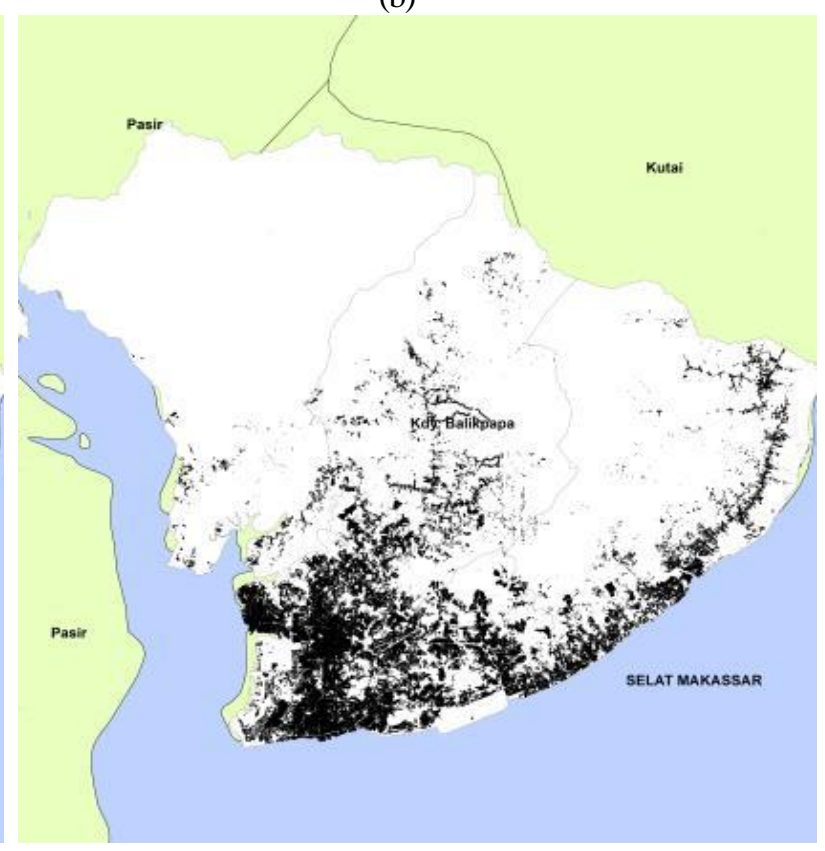

(d)

Fig. 1. Solid-Void Maps of the development of Balikpapan City (a) 1987, (b) 1996, (c) 2016, (d) 2019

connectivity means that the street is connected with many streets. Integration measures how integrated (or central) a street is to a network. A high score of Integration signifies the configuration of streets that are well connected to its network. Choice measures how important street is as a through-road for the network. Choice describes the alternative options for the users when they want to make a detour in their movement. The colors in the axial lines map represent the value that the observed areas contain. The highest to the lowest score is represented by red, orange, yellow, green, turquoise, blue, and grey. This colored axial lines map would define Balikpapan's spatial characteristics.

\section{Defining the Spatial Configuration of the City}

After the analysis of the connection of the old center and the new center of development was obtained, the spatial configuration of Balikpapan city could then be defined and explained. The mentioned research process can be seen in Figure 2. 


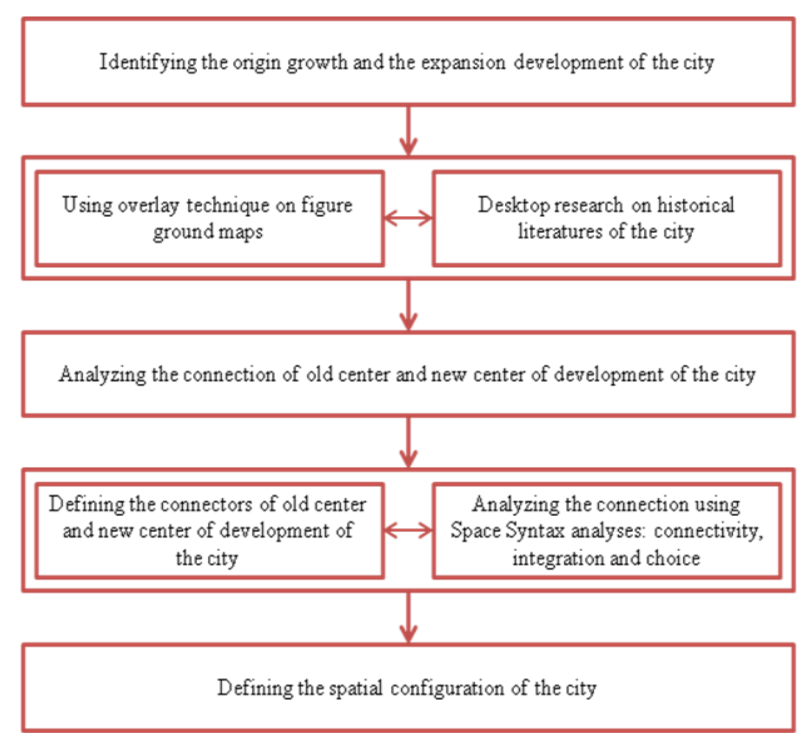

Fig. 2. The Research Process (Source: authors).

\section{DISCUSSION AND RESULTS}

\section{The Old Center and the New Center of Develop- ment of Balikpapan City}

Balikpapan is a coastal city located in East Kalimantan province in Indonesia which bordered by Kutai Kartanegara Regency to the North, Penajam Paser Utara Regency to the West, and Makassar Strait to the South and East (BPS Kota Balikpapan, 2019). The study found that the origin growth of Balikpapan city was around Mathilda Oil Well that was found in 1897. The Oil Well and the emergence of Dutch oil trading company De Bataafsche Petroleum Maatshappji $N V$ which then called BPM as the operator of the oil well triggered the development of Balikpapan which turning the coastal fishermen settlements into a city. After the independence of Indonesia, PT Pertamina took over the management of the oil company and the surrounding area developed into PT Pertamina quarter which consisted of oil refineries, offices, and company residential areas (Tarigan, Samsura, Sagala, \& Wimbardana, 2017). The PT Pertamina quarter grew side by side with the settlements in Klandasan, Prapatan, Gunung Pasir, Gunung Sari, Karang Jawa, and Karang Jati, the authors called these areas as the old center of development of Balikpapan city.

As can be seen in Figure 4. (b), the city then expanded, thus new center of development emerged in Pandansari Market (Matanasi, 2015). The area around Pandansari Market then grew into settlement and trading area. The area also expanded to the north side following the coastal line. The authors called this area as the new center of development of Balikpapan city.

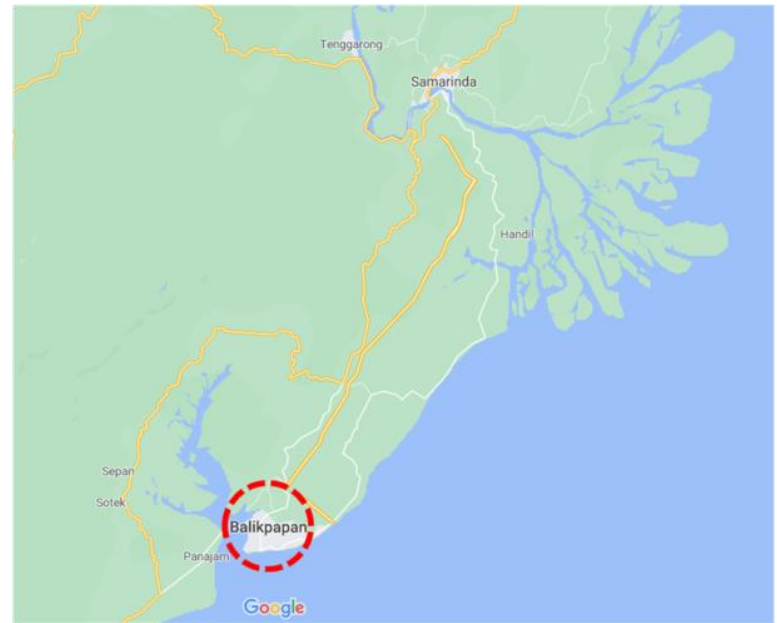

Fig. 3. (a) The Location of Balikpapan City. (Source: Google Maps).

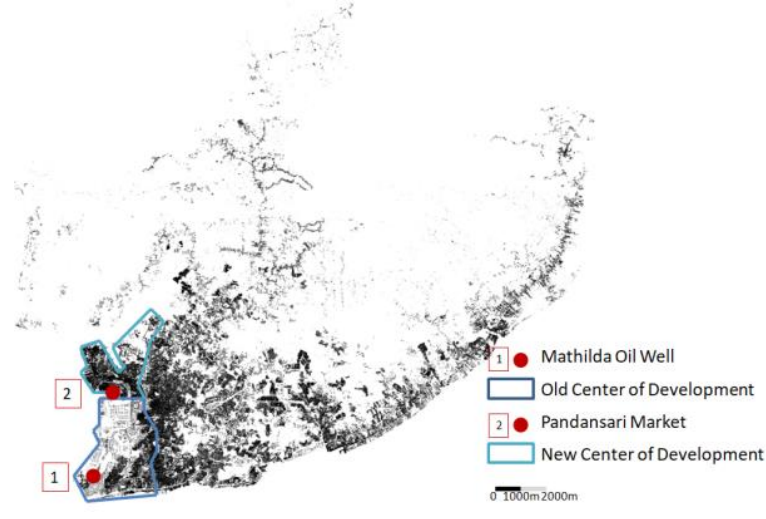

Fig. 4. (b) The Old Center and the New Center of Development of Balikpapan City

\section{The Main Connectors of Old and New Center of Development of Balikpapan City}

The old center and the new center of development of Balikpapan city is linked and connected by streets. There are main streets that connect the two centers which in Figure 5 are represented by Connector Street 1. Connector Street 1 represents Jalan Yos Sudarso (in the old center of development) and Jalan Letjen Suprapto (in the new center of development). In the meeting point of these two centers, there is Connector Street 2 which represents Jalan Ahmad Yani. This Connector Street 2 links Jalan Yos Sudarso and Jalan Sudirman thus creating a loop in the old center of development area. Half of this loop is represented by Connector Street 3. Jalan Ahmad Yani of Connector Street 2 also links Jalan Letjen Suprapto and Jalan Klamono which creating a loop in the new center of development area. The streets in this loop are Jalan Letjen Suprapto, Jalan Ahmad Yani, Jalan Klamono, Jalan Telindung, Jalan Baru, and Jalan Wolter Monginsidi. Half of the loop in the new center of development area is also represented by Connector 
Street 3. Connector Street 3 signifies the expansion and development of the two centers. The two centers expanded and developed which created new streets of Connector Street 3 linking Connector Street 1 through Connector Street 2 which in turn created a perfect loop of connectors.

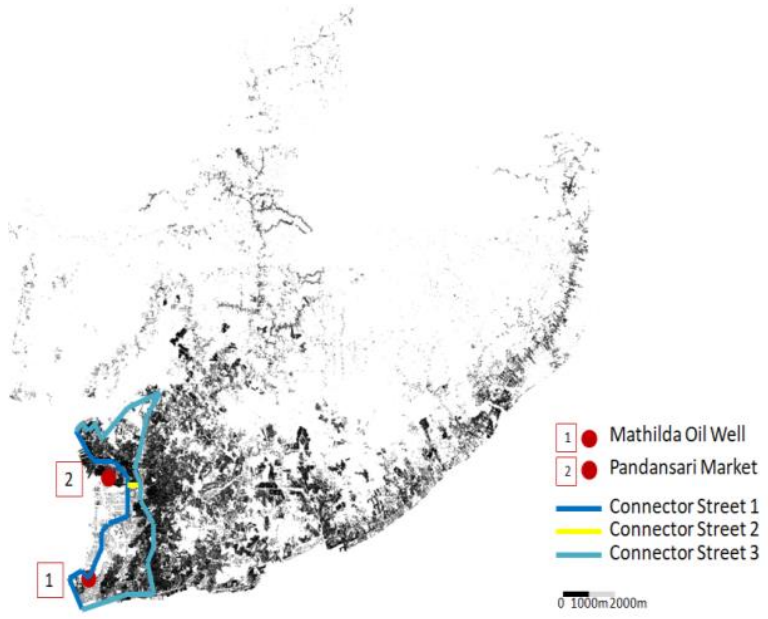

Fig. 5. The Main Connectors of Old Center and New Center of Development of Balikpapan City

\section{Space Syntax Analyses - Connectivity, Integration and Choice}

Space Syntax analyses are applied to the drawn axial lines map which signifies the movement spaces of observed areas: the old center and the new center of development of Balikpapan city. Connectivity in Space Syntax analyzes the streets that are connected to a street in the observed areas. The result of Connectivity analysis of the two centers in Balikpapan city shows lower scores of connectivity as represented by the blue colors which are dominant in the axial lines map represented by Figure 6 . This means that most of the streets within the observed network have low connection. In other words the streets connected to only one or two streets.

There is one red color that emerges in the axial lines map which represents Jalan Sudirman in the old center of development of Balikpapan city. Furthermore, one yellow color also emerges in the new center of development of Balikpapan city which represents Jalan Letjen Suprapto. This means that these two streets have higher connection compared to other streets within the observed network. Though, comparing with the dominant blue lines, these two high score lines seem small. Overall, the result renders the connectivity of the old and the new center of development of Balikpapan city to be low.

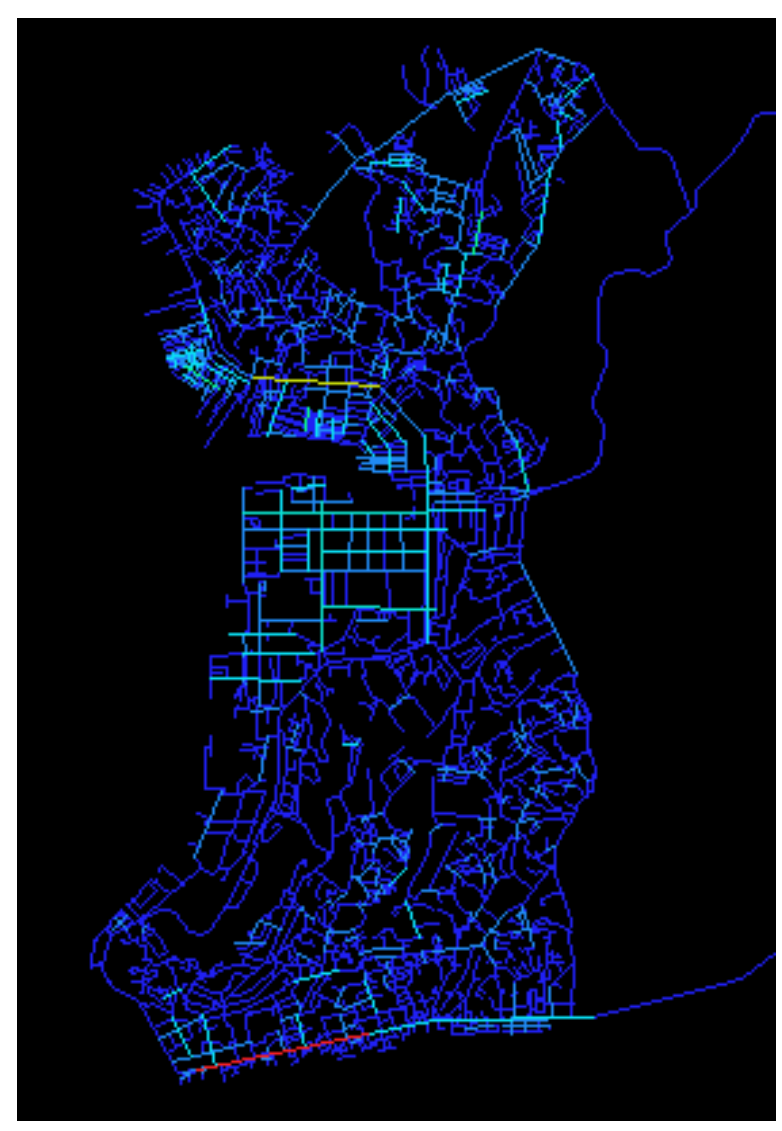

Fig. 6. Connectivity Analysis on Old Center and New Center of Development of Balikpapan City

Integration in Space Syntax analysis measures the integration of a street to its network, to define whether the observed street is well integrated or not to its network. The result of Integration analysis on the old center and the new center of Balikpapan city shows low scores of integration where blue lines, again, dominate the axial lines map presented in Figure 7. Even lower is the axial lines map also shows grey lines which have lower score than blue lines. For lines scoring higher than blue lines, there are several turquoise colored lines in the old center of development which represent Jalan Sudirman, a part of Jalan Ahmad Yani, and a part of Jalan Yos Sudarso. In the new center of development, a part of Jalan Letjen Suprapto, a part of Jalan Wolter Monginsidi and a part of Jalan Klamono also represented by turquoise colored lines. This means that the configuration streets of the old and the new center of development of Balikpapan city are not well integrated with its network. In other words, it is difficult for a user to perceive the spatial configuration in his mind, which will make him easy to get lost when navigating the network. 


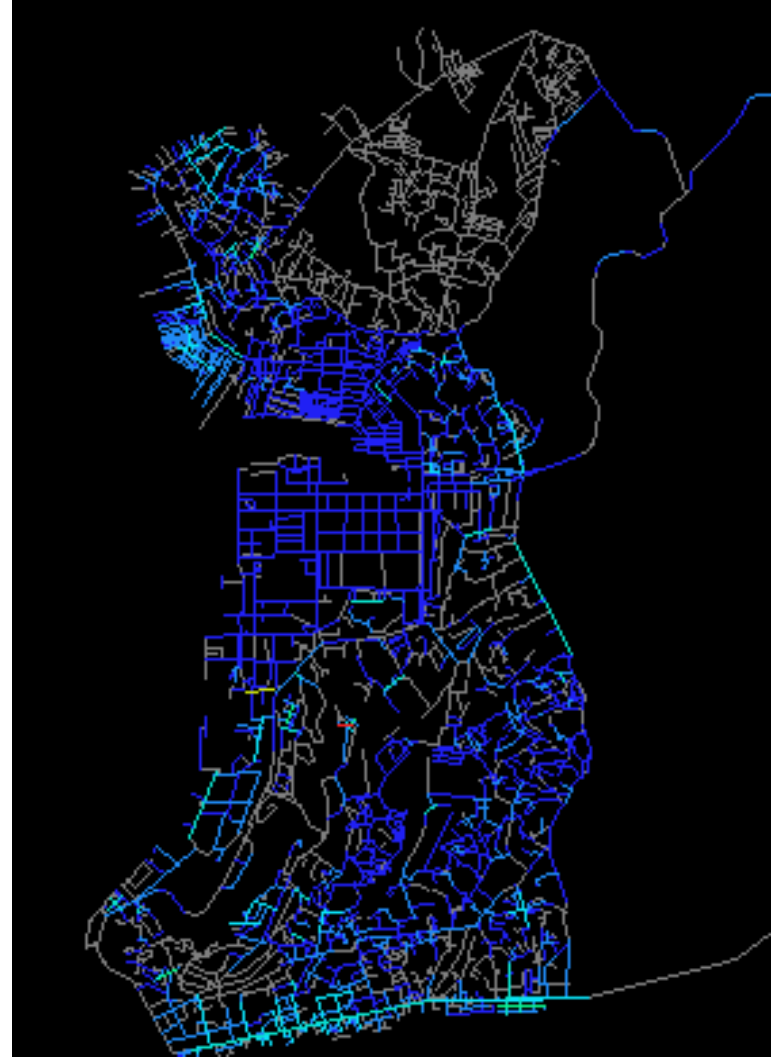

Fig. 7. Integration Analysis on Old Center and New Center of Development of Balikpapan City

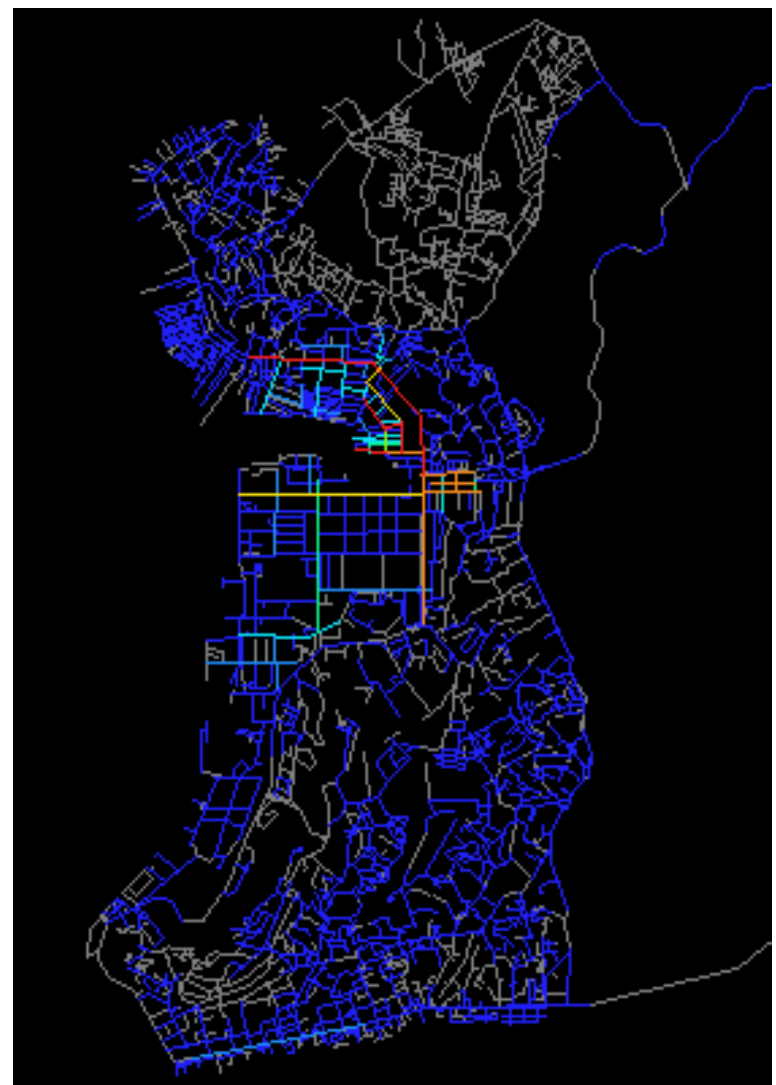

Fig. 8. Choice Analysis on Old Center and New Center of Development of Balikpapan City

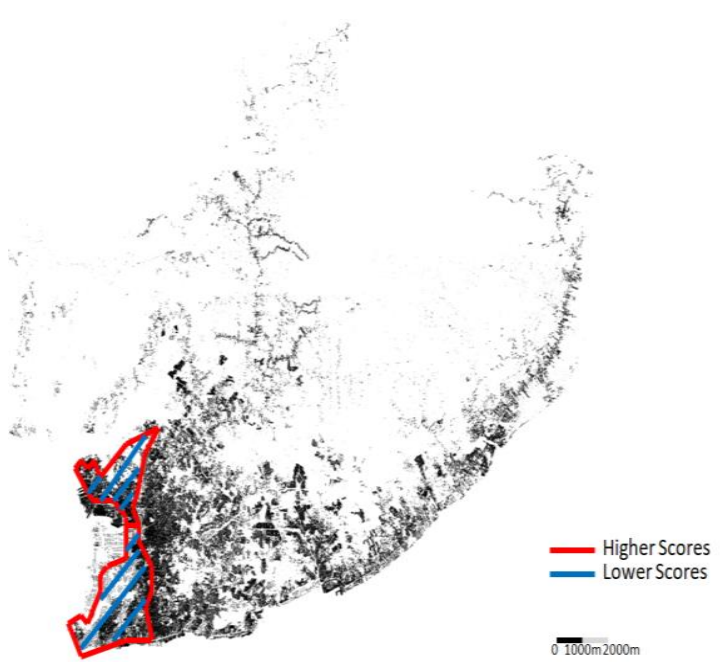

Fig. 9. The Spatial Configuration's of Old Center and New Center of Development of Balikpapan City

Choice in Space Syntax analysis measures how important street is as a through-road for the network. Choice describes the alternative options for the users when they want to make a detour in their movement. The result of Choice analysis on the old and the new center of development of Balikpapan city shows low scores of choice where blue and grey lines dominate the axial lines map. The map also shows red lines in the area of the new center of development (Jalan Letjen Suprapto), orange lines in the area of Connector Street 2 (Jalan Ahmad Yani) and a part of Jalan Yos Sudarso. This means that the old and the new center of development of Balikpapan city mostly have low choices of movement or detour options except in Jalan Letjen Suprapto, a part of Jalan Ahmad Yani and a part of Jalan Yos Sudarso. On the streets which have higher score of choice analysis would make the streets more accessible while also adds the options for the users when they need to make a detour.

\section{Spatial Configuration of Balikpapan's Old and New Center of Development}

From Space Syntax analyses on the old and the new center of development of Balikpapan city, the study obtained that the spatial configuration of those two centers has low score of connectivity, integration and choice on the local streets within the observed areas, and higher scores on the main connectors of the two centers. This result is heavily influenced by the physical condition of Balikpapan city which is contoured within the observed area (Karya, 2016), in addition of the low accessibility in the local streets hence the low scores. Furthermore, the relatively flat contour and the higher accessibility of the main connectors are the reason why its scores are higher. 
The result defines the movement and accessibility of the main connectors which are easier than of the local streets. This result also shows the spatial perception of users on the spatial configuration which is integrated in the main connectors and segregated in the local streets. This is the spatial configuration of Balikpapan's old and new center of development.

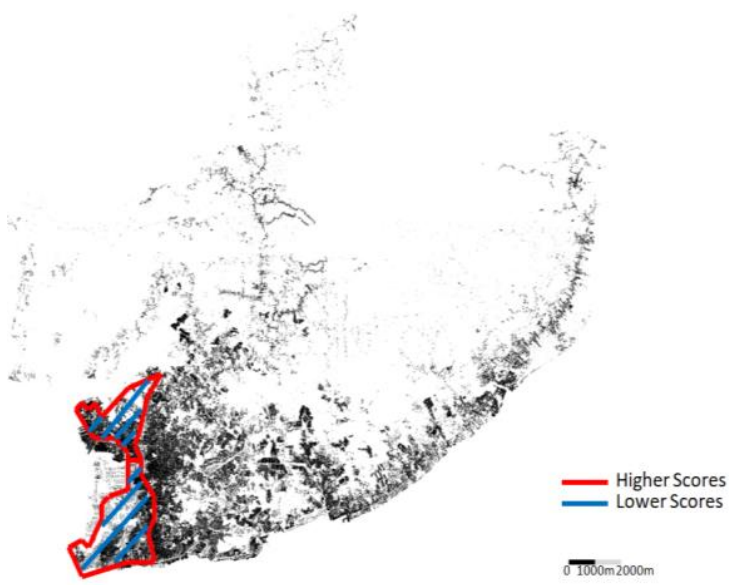

Fig. 9. The Spatial Configuration's of Old Center and New Center of Development of Balikpapan City

\section{CONCLUSION}

Table 1. Methodology's SWOT Analysis

\begin{tabular}{ll}
\hline STRENGTH & $\begin{array}{l}\text { Space syntax analyses help defining } \\
\text { the spatial configuration of Balikpapan } \\
\text { city quantitatively. }\end{array}$ \\
\hline WEAKNESS & $\begin{array}{l}\text { Lack of information on other variables } \\
\text { such as topography, land use, building } \\
\text { heights, et cetera, which could explain } \\
\text { the low results of Space Syntax analy- } \\
\text { ses. }\end{array}$ \\
\hline OPPORTUNITY & $\begin{array}{l}\text { Combination with other urban mor- } \\
\text { phology approaches would strengthen } \\
\text { the analyses. }\end{array}$ \\
\hline THREAT & $\begin{array}{l}\text { Questionable validity on Space Syntax } \\
\text { measurements if not supported with } \\
\text { valid data. }\end{array}$ \\
\hline
\end{tabular}

Space Syntax analyses helped defining the spatial configuration of the old and the new center of development of Balikpapan city which has been shown in the results. As represented in Figure 9, the spatial configuration has higher scores in main connectors and lower scores in local streets which also defines the movement and accessibility of the observed area.

For the lower scores that have been identified in some part of the main connectors and in the most of local streets, the challenges and potentials emerge to improve the scores of its connectivity, integration and choice within the networks. Higher scores mean higher connectivity, a well integrated network and higher accessibility of streets. This would take interventions that needed to be carried out by several stakeholders such as the city's government, the academician, urban planner, and urban designer.

According to the methodology's SWOT analysis, there are limitations from this study that can be seen in Table 1. Although Space Syntax alone could define the spatial configuration of Balikpapan city quantitatively, but the information regarding other variables which could explain the low results of the Space Syntax is still lacking. Thus, the combination with other urban morphology approaches is needed to strengthen the analyses. In addition, the obtained data should be valid in order to guarantee the validity of the Space Syntax measurements.

This study also recommends continuing the study of the connection of other centers in Balikpapan city to obtain a comprehensive spatial configuration of the whole city. The authors hope that the results of this study can be considered in guiding the planning and designing of the future development of Balikpapan city which is appropriate with its spatial configuration characteristics.

\section{ACKNOWLEDGMENT}

This research financially supported by Lembaga Penelitian dan Pengabdian Masyarakat Institut Teknologi Kalimantan fiscal year 2020.

\section{REFERENCES}

Badan Pusat Statistik Kota Balikpapan. (2019). Kota Balikpapan dalam Angka 2019. BPS Kota Balikpapan, Balikpapan.

Hillier, B., \& Hanson, J. (1984). The Social Logic of Space. Cambridge University Press, Cambridge.

Hillier, B., Burdett, R., Peponis, J., \& Penn, A. (1986). Creating life: or, does architecture determine anything? Arch.\& Comfort/Arch. Behavior, 3(3), 233-250.

Hillier, B. (1996). Space is the Machine. Cambridge University Press, Cambridge.

Karya, C. (2016). Laporan Final: Bantuan Teknis Pendampingan Penyusunan Dokumen RPIJM Kota Balikpapan. Cipta Karya, Balikpapan.

Kropf, K. (2009). Aspects of urban form. Urban Morphology, 13(2), 105-120.

Kropf, K. (2011). Morphological Investigations: Cutting into the Substance of Urban Form. Built Environment, 37(4), 393-408.

Oliveira, V. (2016). Urban Morphology: An Introduction to the Study of the Physical Form of 
Cities. Springer International Publishing, Switzerland.

Matanasi, P. (2015). Balikpapan Tempo Doeloe. Sibuku Media, Yogyakarta.
Tarigan, A.K.M., Samsura, D.A.A., Sagala, S., \& Wimbardana, R. (2017). Balikpapan: Urban planning and development in anticipation of the post-oil industry era. Cities, 60, 246-259. 